\title{
DEREGULATION AND ACCESS TO UNIVERSITY EDUCATION: OPINION OF STAKEHOLDERS IN ABU ZARIA
}

\author{
${ }^{1}$ B.A. MAINA PhD, ${ }^{2}$ MAL. M.I. TANIMU AND ${ }^{2}$ A. M. JUMARE
}

\begin{abstract}
The study was set to assess the opinion of respondents on the policy of university deregulation and examine the consequence of deregulation on access to university education. Research questions and hypotheses were also constructed according to the objectives. The respondents were 50 parents, 50 lecturers and 100 students. 200 questionnaires were distributed, but retrieved 165. The questionnaire contained item statement deducted from the research questions with 5 scale likert style. The data was analyzed using frequencies and percentages. Hypotheses were tested using Analysis of Variance (ANOVA), where the two hypotheses were rejected. The study found that deregulation separate from intellectual activity. It is recommended that educational planners and curriculum developers should make sure quality education is never comprised.
\end{abstract}

\section{Introduction}

Higher education in Nigeria began when the need for high level manpower increased in the 1940's. Thus, the London university satellite campus was established in Ibadan. The main purpose for the university to establish the campus was to train high level manpower that will man government offices. Therefore, the need then was from government, hence government made all efforts to educate the citizens. These efforts were seen through the provision of free tuition fee, accommodation, and all that is required for a student to study. In fact students were given scholarships in addition to all the above provisions. Adeogun (2009) submits that education especially at the university level is regarded as a vehicle for social and economic transformation, which makes its provisions to become paramount. Also Subair (2008) argued that the entire intellectual and professional life of a country depend on sound higher education.

It is against this background that mixed opinion and views exist among citizens and government on whether to deregulate education or not and whether deregulation is a setback on access to education to a common man.

\section{Concept of Deregulation}

The term deregulation is an economic terminology; it is usually applicable in almost all sectors of development. The physical aim of its application is to improve efficiency in government affairs. Akinwumi, Isuku and Agwaranze (2005) opine that deregulation is the removal of government interference in running of a system. In other words, means of production should determine their way by giving consumers opinion. Deregulation focuses on the so-called "old-style economic regulation" which intends to determine business parameters and influence decisions like market entry, price and product quality (Kasperk, 1996). Also Ernest and Young (1988) argued that deregulation and privatization are element of economic reform programme charged with the ultimate goal 
of improving the overall economy through spelt out ways. This indicated that deregulation is an economic approach in runing public affairs with the sole aim of profit making through competition. In fact Encarta Encyclopedia (2003) stated that deregulation is based on the doctrine of laissez faire that favors capitalist self-interest competition and natural consumer preferences as force leading to optional prosperity and freedom.

\section{What is Education Deregulation?}

The term deregulation could be applied to almost all sectors of development. In education deregulation implies sale of knowledge to the highest bidder and the possible lowering of standards for the attraction of customers (Kaplan, 2002; Olalubosun, 2005). In addition, Encarta Encyclopedia (2003) viewed education deregulation as education becoming a private enterprise undertaken by private individuals or corporate bodies that hope to maximize profit from their investment in education. In a related explanation Caldwell and Spinks (1992) relates that deregulation of education means relaxing or dismantling the legal and government restriction on the operation of education business. All these shows that education deregulation implies handing over education to private sector for reasons of improvement and better services.

\section{Why Deregulation?}

Governments and proponents of deregulation have been advancing reasons and benefits of deregulation. Johston (1988) captured the government's policy plan for deregulation as:

a. Restructure and rationalize the public sector in order to lessen the dominance of unproductive investment in the sector;

b. Re-orientate the enterprises for privatization and consumer socialization towards a new horizon of performance improvement, viability and overall efficiency;

c. Ensure positive returns on public sector investments in commercialized enterprises;

d. Check the present absolute dependence on treasury for funding the otherwise commercially oriented parastatals and encourage their approach to the capital market; and

e. Initiate the process of gradual release to the private sector of such public enterprises, which by their nature and type of operations are best, performed by the private sector.

In a related argument on why deregulation, Obadan (2004) opines that deregulation will:

a. Ensure that the rate of competition within the market is in the best interest of the consumer;

b. Protection of the weak from the excessive control of the indivisible hands, which tend to pre-dominate the market arena;

c. Availability of the quality and quantity of goods and services which must be made available at affordable prices; and 
d. The need for the major stakeholders to enhance reduction in prices of consumable goods as this could make such goods affordable for the teeming populace for their consumption.

However, the big questions Nigerian's may ask could be: how real are these laudable projections? In the event of failure what will happen? Is it not government officials that own the private sector today? Can the son of the poor go to school?

On education specifically, Nwadiani (2001) argued that deregulation of education will bring about solution to overcrowding, and do away with deteriorating physical facilities, creates competition between private and public educational institutions, provide the public with alternative in funding education, create avenue for variety of courses to citizens and enable citizens to have better academic environment with better modern facilities. The question also one may ask could be: does it mean that government can do all these in the public universities? If yes then what is the role of the government in fulfilling its function as enshrined in section 18:1 of the (1979) constitution and Nation Policy on Education (2004), Baikie (1999) which stipulates the provision of equal access to educational opportunities for all citizens of the country at primary, secondary and tertiary levels?

\section{Concept of Access to Education}

Access to education means getting children into schools and keeping them there, ESSPIN (2010). National Policy on Education (NPE 2004) defined access to education as making it possible for everyone who is entitled to education to receive it. Torwe (2005) and Dada (2004) see access to education as the right to receive formal education as distinct from informal education. This definition viewed the concept from the legal point of view. While UNESCO (2003) opines that access to tertiary education means "ensuring equitable access to tertiary education institutions based on merits, capacity, efforts and perseverance". This definition implies that everyone is entitled to higher education when he is qualified i.e. having the requirements, healthy and fit to study, and will be able to with stand the educational challenges mentally and physically. While equity means giving the individual an equal chance of selection. This could be after qualifying examination or any other means of selection, however fairness in the process must exist.

\section{Statement of the Problem}

Right to education is guaranteed by the Nigerian constitution to every citizen. But due to reasons known to government very few citizens have access to higher education in Nigeria. In the opinion of many deregulations is a modernized means of denying access to education to citizens, especially in higher education. Inadequate access to higher education is invariably inadequate access to development in the community of nation. Nigeria with acute shortage of high level manpower, the dream of becoming one of the 20 largest economies by the year 2020 will be a mirage. Sales of public or government universities to private owners will make access education, only to the sons of the haves. 


\section{Objectives of the study}

1. Assess the opinion of respondents on the importance of policy of university deregulation in Nigeria.

2. Examine the consequence of deregulation policy on access of university education in Nigeria.

\section{Research Questions}

1. What are opinions of respondents on the importance policy of university education deregulation?

2. What are the consequences of deregulation policy on access to university education in Nigeria?

\section{Hypotheses}

1. There is no significant difference in the opinion of parents, students and lecturers on the importance of policy of university deregulation in Nigeria.

2. There is no significant difference in the opinion of parents, students and lecturers on the consequence of deregulation on access to university education in Nigeria.

\section{Method}

Adopted for the research as a design was survey design. This design is appropriate for opinion sampling and making conclusions from the population (Nworgu, 1991). The population of the study was finite, therefore, approximation was made to sample 50 lecturers, 30 parents, and 100 students from Ahmadu Bello University, Zaria. The instrument was validated through vetting by experts in language and education, which some corrections and additions were made.

A questionnair was used to collect data. The questionnaire had 20 item statements seeking the opilion of respondents on the topic of study. Also used was a five Likert scale which are strongly Agreed (SA); Agreed (AG); Undecided (UN); Strongly Disagreed (SD) and Disagreed (DA).

The date was analyzed using t-test and Analysis of Variance (ANOVA) since the respondents have three categories. The results were presented in tables through frequencies and percentages with explanation of the responds, views.

\section{Data Presentation and Analysis}

\section{Research Question I}

Research Question I seeks the opinion of respondents (agree or disagree) on the importance policy of university education deregulation. Table I explained details of the opinions. 
Table 1: Opinion of Respondents on Importance Policy of University Deregulation Education in Nigeria.

\begin{tabular}{|c|c|c|c|c|c|c|c|}
\hline \multirow[b]{3}{*}{$\mathrm{S} / \mathbf{N}$} & \multirow[b]{3}{*}{ Item Statement } & \multicolumn{6}{|c|}{ Responses } \\
\hline & & \multicolumn{2}{|c|}{ Agreed } & \multicolumn{2}{|c|}{ Undecided } & \multicolumn{2}{|c|}{ Disagreed } \\
\hline & & $\mathbf{F}$ & $\%$ & $\mathbf{F}$ & $\%$ & $\mathbf{F}$ & $\%$ \\
\hline 1 & $\begin{array}{l}\text { Deregulation will increase } \\
\text { access to university } \\
\text { education in Nigeria }\end{array}$ & 42 & $27 \%$ & 17 & $10 \%$ & 106 & $63 \%$ \\
\hline 2 & $\begin{array}{l}\text { Deregulation will address } \\
\text { problems of scarce } \\
\text { educational resources in } \\
\text { Nigeria }\end{array}$ & 55 & $28 \%$ & 23 & $15 \%$ & 93 & $57 \%$ \\
\hline 3 & $\begin{array}{l}\text { Deregulation will improve } \\
\text { quality of university } \\
\text { education in Nigeria }\end{array}$ & 14 & $24 \%$ & 11 & 19 & 31 & $57 \%$ \\
\hline 4 & $\begin{array}{l}\text { Deregulation of university } \\
\text { resources is to Nigeria with } \\
\text { world practices }\end{array}$ & 14 & $25 \%$ & 11 & $19 \%$ & 30 & $58 \%$ \\
\hline 5 & $\begin{array}{l}\text { Deregulation of university } \\
\text { education will reduce the } \\
\text { social gap between the vice } \\
\text { and the pour }\end{array}$ & 16 & $31 \%$ & 13 & $25 \%$ & 22 & $44 \%$ \\
\hline 6 & $\begin{array}{l}\text { Deregulation of university } \\
\text { will bring concept aid } \\
\text { thereby reduce study fees }\end{array}$ & 18 & $31 \%$ & 9 & $16 \%$ & 25 & $53 \%$ \\
\hline
\end{tabular}

Item 1 in table 1 indicates that majority of respondents (63\%) disagreed that deregulation will increase access to university education in Nigeria. item 2 in table 1 shows that majority of respondents $(57 \%)$ disagreed that deregulation of university education will address the problems of scheme educational nation refers in Nigeria. item 3 in table 1 indicates that majority of respondents $(57 \%)$ agreed that deregulation of university education will improve the quality of education in Nigeria item 4 in table 1 shows that majority of respondents (58\%) agreed that deregulation of university education in Nigeria is to align to world process item 5 in table 1 shows that majority of respondent (44\%) agreed/disagreed that deregulation of university education in Nigeria will reduce the solid gap between the via and pour item 6 in table 1 shows that majority of the respondents disagreed with $53 \%$ that deregulation of university will bring complex and thereby reduce social gap between the realistic poor. 
Table 2: $\quad$ Opinion of Respondent on the Consequence of Deregulation on Access to University Education

\begin{tabular}{|c|c|c|c|c|c|c|c|}
\hline \multirow[b]{3}{*}{$\mathbf{S} / \mathbf{N}$} & \multirow[b]{3}{*}{ Item Statement } & \multicolumn{6}{|c|}{ Responses } \\
\hline & & \multicolumn{2}{|c|}{ Agreed } & \multicolumn{2}{|c|}{ Undecided } & \multicolumn{2}{|c|}{ Disagreed } \\
\hline & & $\vec{F}$ & $\%$ & $F$ & $\%$ & $\mathbf{F}$ & $\%$ \\
\hline 7 & $\begin{array}{l}\text { Quota system in education } \\
\text { brings corruption }\end{array}$ & 19 & $35 \%$ & 08 & $15 \%$ & 28 & $51 \%$ \\
\hline 8 & $\begin{array}{l}\text { Deregulation doing students } \\
\text { with low economic status } \\
\text { access and university } \\
\text { education }\end{array}$ & 16 & $28 \%$ & 10 & $18 \%$ & 29 & $63 \%$ \\
\hline 9 & $\begin{array}{l}\text { Deregulation will bring high } \\
\text { school tuition fees }\end{array}$ & 24 & $39 \%$ & 11 & 20 & 21 & $40 \%$ \\
\hline 10 & $\begin{array}{l}\text { Deregulation of university } \\
\text { education will reduce } \\
\text { graduate due to poverty in } \\
\text { nigerian. }\end{array}$ & 21 & $37 \%$ & 09 & $16 \%$ & 25 & $47 \%$ \\
\hline 11 & $\begin{array}{l}\text { Deregulation of university } \\
\text { education will create class } \\
\text { schools }\end{array}$ & 17 & $31 \%$ & 09 & $17 \%$ & 29 & $51 \%$ \\
\hline 12 & $\begin{array}{l}\text { Deregulation separates } \\
\text { education from intellectual } \\
\text { activity }\end{array}$ & 21 & $40 \%$ & 10 & $17 \%$ & 21 & $42 \%$ \\
\hline
\end{tabular}

Item 7 in table 2 indicates that majority of respondents $50 \%$ disagreed that quata system in education brings corruption. Item 8 shows that $63 \%$ disagreed with the statement that says deregulation deny students with low economic status access to university education. Item 9 reveals th at $40 \%$ disagreed with the statement that solicit opinion on deregulation with bring high : shool tuition fees. While in item 10,47\% disagreed with the statement on deregulation of university education will reduce graduate due to poverty in Nigeria. Item 11 was disagreed with $51 \%$ on deregulation of university education will create class schools. The last item 12 was agreed with $42 \%$ on deregulation separates education from intellectual activity.

\section{Hypothesis I}

There is one significant difference between the opinion of parents, lecturers and students on policy of university deregulation. Table 3 shows details.

Table 3: Showing Analysis of Variance on the Opinion of Parent, Lecturers and Students on Importance Policy of University Deregulation.

\begin{tabular}{llllllll}
\hline Designation & $\begin{array}{l}\text { Sum of } \\
\text { squares }\end{array}$ & $\begin{array}{l}\text { Mean } \\
\text { squares }\end{array}$ & Df & F. ratio & Prob & $\begin{array}{l}\text { T. } \\
\text { critical }\end{array}$ & Remark \\
\hline Between Group & 26.013 & 1.041 & 25 & 1.716 & 0.027 & 1.88 &
\end{tabular}




\begin{tabular}{llll} 
Within Group & 84.290 & 606 & 119 \\
Total & 110.303 & 163 & 164 \\
\hline
\end{tabular}

The table 3, shows, that the calculated F. ratio (1.716) at $25 \mathrm{df} 139$ at the level of 0.05 . The f. critical (1.88) was found to be greater than f. ratio (1.716) and observed level of significance $\mathrm{p}(0.027)$ is less than 0.05 therefore, the null hypothesis which states that this is as signified differ between the opinion of parents, lecturers and students on policy of university deregulation is rejected.

\section{Hypothesis II}

Hypothesis II states that there is difference between the opinion of parents, lecturers and students on the effect of deregulation on access to university education. Table 3.5 shows the details of the result.

Table 4: Analysis of Variance on the Opinion of Parents Students and Lecturers on the Consequences of Deregulation on Access to University Education.

\begin{tabular}{llllllll}
\hline Designation & $\begin{array}{l}\text { Sum of } \\
\text { squares }\end{array}$ & $\begin{array}{l}\text { Mean } \\
\text { squares }\end{array}$ & Df & $\begin{array}{l}\text { F. } \\
\text { ratio }\end{array}$ & Prob & $\begin{array}{l}\text { T. } \\
\text { critical }\end{array}$ & Remark \\
\hline Between Group & 28.276 & 0.943 & 30 & 1.540 & 0.51 & 1.88 & \\
Within Group & 82.027 & .612 & 134 & & & & \\
Total & 110.303 & 163 & 164 & & & & \\
\hline
\end{tabular}

F $(30,134) 1.88<0.05$

Table 4 shows that the calculated F.ratio (1.540) at $25 \mathrm{df} 134$ at the level of 0.05 . The F. critical (1.88) was found greater than F. ratio (1.88) and observed level of significance $P$ $(0.51)$ is less than 0.05 . Therefore, the null hypothesis which state that there is significant difference in the opinions of Parents, Lecturers and Students on the effect of deregulation on access to university education is hereby rejected.

\section{Discussion}

On the opinion of respondents on the importance of deregulation of university education in Nigeria. The responses as shown as item 1, deregulation will not increase access to education in Nigeria. This response is in agreement with the critics of deregulation that deregulation will create more problems to students going to school. Item 2 deregulation will not reduce scarce of educational resources. This response is also in a agreement with the critics of deregulation policy. This implies that solution to acute shortage of educational resources is not deregulation. Item 3 is responses shows that deregulation cannot improve quality of university education. Reasons for this could be referred to some privatized sectors in Nigeria. Item 4 shows that deregulation effort is not to align with world practices. This could be translated to the university Nigerians do manage sectors of development. This opinion disagrees with critics of deregulation of education. 
Item 5 and 6 indicates disagreement with the statement respectively. That deregulation will bring about social gap and competition thereby reducing schools fees. These opinions are in disagreement with the critics of deregulation, who sees deregulation as a means of creating social gap and competition in university systems. Obadan (2004) posits that deregulation protect the weak. Item 7 show that the response disagree that quarter system brings about corruption. This implies that allocation of limited admission to geopolitical zones of state does not bring about corruption. Item 8 shows disagreement that deregulation can become a barrier to access to education especially to those with how income status. This agrees with the position of Obadan (2004). Item 9 indicates that respondents disregards the statement that deregulation of education will bring high school tuition fees. This agrees with the position of Johnston (1188). Tem 10 shows disagreement that deregulation will reduce graduate in Nigeria due to poverty. Obadan (2004) share the same opinion with the mentioned opinion, that deregulation can generate complete thereby reducing high rate of school fees. Item 11 shows disagreement that university deregulation with create clan schools. in other words, all category of people will have access to university education irrespective of status. Item 12 agreed that deregulation of education will separate intellectual activity from education. This agrees with the new of Caldwell and Spinks (1992)

\section{Major Findings}

1. Deregulation will not increase access to university education in Nigeria.

2. Deregulation will not be able to solve the scarcity of educational resources in Nigerian universities.

3. University education deregulation will not reduce social gap the rich and the poor in Nigeria.

4. Deregulation of university education will not deny students with low economic status access to education.

5. Deregulation separate direction from intellectual activity.

\section{Recommendations}

1. Government should develop other means such as mobilization, enlightment, establishment of more universities so as to increase access to university education in addition to other means.

2. University education needs more funds to solve scarcity of educational resources. This could be through tax to all and sundry to assist university education in addition to tetfund effort.

3. Government should put in place mechanism to ensure that deregulation of university education does not create social gap between the rich and the poor. This could be through average school tuition fees.

4. Educational planners and curriculum developers should make sure quality education is never compromised in the process of deregulation. 


\section{Conclusions}

In conclusion, it is our belief that policies that work in some countries might not work in Nigeria due to difference in culture, awareness, beliefs and development. Therefore, from the foregoing, this shows that educational policies can only be effective when there is effective consultation. Education is a right by all citizens not a privilege.

\section{References}

Adeogun, A. A (2009). Deregulation of University Education in Nigeria: Problem and Prospects. Journal of Educational Administration Policy, 3 (Issue II).

Akinwum, F. S.; Isuku, E. J.; \& Agwaranze, D. I. (2005). University Education Deregulation: Pros and Cons”. In G. O. Akpa; Su. Udoh and E. O. Fagbamiye (Eds) Deregulation the Provision and Management of Education in Nigeria. NAEAP Publication. Jos. Nigeria: M.P. Ginae Concept Ltd.

Baikie, A. (1991). Keynote address at the $13^{\text {th }}$ Annual Congress of the Academy of Education held at Federal College of Education Kano, $16^{\text {th }}-20^{\text {th }}$ November.

Caldwell, B. J. \& Spinks, J. (1992). Leading the self-managing school. London. The Falmer Press.

Dada, J. A. (2004) Access to Education in Democratic Nigeria: Issues and Problems. In Uya, E. O.; Dengay, D.; Umeh, J.; and Okoro, J. (Eds) Education for Sustainable Democracy: The Nigerian Experience. Calabar. University of Calabar Press.

Encarta Encyclopedia (2003). Deregulation C.D. Rom.

Ernest, P. \& Young, E. (1988). The Colonial State and Postcolonial Crisis. In the transfer of power 1960-1980. New Haven and London. Tale University Press.

Federal Republic of Nigeria (2004). National Policy on Education Lagos. NERDC Press.

Johnston, M. (1998). Fighting Systematic Corrupting Social Foundation for Development. London. Frak Cass Press

Kaplan, D. (2002). Education is not a commodity. A Paper Presented at the International Conference Against Deregulation help. In Baylin, Germany.

Kasperk, G. (1997). Deregulation and Privatization. Deregulierung des Elekatrizitatssektors in Entwickclusgslandern. Baden-Baden. Germany.

Nwadiani, M. (2000). Economic Dimensions of Educational Planning in Nigeria Theory and Practice. Benin City. Monose Amalgamates Publishers.

Obadan, M.I. (2004). The Nigerian Economy and External Sector Lagos. CASS

Olahunbosun, O. (2005). Deregulation of Education. Comment on education in Nigeria on Twitter. Retrieved on 22 August 2012.

Subair, S.T. (2008). Infrastructure, welfare services and students perceived motivating to learning in universities in south-west Nigeria. Unpublished PhD Thesis. Lagos. University of Lagos

Tonwer, U.A.C. (2005). Accessibility and Equity in Secondary Education in Delta State in a Deregulated School System. In Akpa, G.O., Udo, S.U. and Fagbamiye, E.O. (Eds) Deregulations the Provision and Management of Education in Administration and Planning (NAEAP), Jos.

UNESCO (2003). Education Web Master. World Conference on Higher Education Framework and Action. www.ivu.tilunesco2003/conference.html. Accessed 30th June $\underline{2011}$ 